\title{
Delocalized $\pi-\pi^{*}$ Orbital Interactions and Stabilization Energies of Phenyltrichlorosilane
}

\author{
Nihal KUS ${ }^{1 *}$ and Saliha ILICAN ${ }^{2}$ \\ ${ }^{1,2}$ Eskisehir Technical University, Science Faculty, Department of Physics, Yunus Emre Campus, Eskisehir, Turkey
}

*Corresponding Author: nkus@eskisehir.edu.tr

Received: 27.02.2020

Accepted: 17.05 .2020

\begin{abstract}
In this study, the optimized Phenyltrichlorosilane (PTS, $\mathrm{C}_{6} \mathrm{H}_{5} \mathrm{SiCl}_{3}$ ) using Density Functional Theory (DFT) with B3LYP/6-311++G(d,p) level was studied using natural bond orbital (NBO) theory with NBO 3.1, as integrated in Gaussian09 program. It was determined that there are only $\pi-\pi^{*}$ transitions for PTS. Donor-acceptor interactions and stabilization energies for these transitions were calculated. The highest transition energy occurred in the orbital interaction of the $\pi(\mathrm{C} 1-\mathrm{C} 6) \rightarrow \pi^{*}(\mathrm{C} 2-\mathrm{C} 3)$ transition and was calculated $c a .99 .32 \mathrm{~kJ} \mathrm{~mol}^{-1}$, which is in a delocolized state. From the NBO calculation results, it was determined that hybridization occurred by settling in p-orbitals of electrons. Natural charges for PTS were calculated and it was determined that the strongest polarization was between Si and C3 atoms. Harmonic Oscillator Measure of Aromaticity (HOMA) index was calculated for the PTS ring.
\end{abstract}

Keywords: Phenyltrichlorosilane, NBO, Stabilization energy, Orbital interaction, Polarization.

\section{Feniltriklorosilanın Delokalize Olmuş $\pi-\pi^{*}$ Orbital Etkileşimleri ve Stabilizasyon Enerjileri}

Öz

Bu çalışmada, B3LYP / 6-311 ++ G (d, p) seviyesi ile Yoğunluk Fonksiyonel Teorisi (DFT) kullanılarak optimize edilmiş Feniltriklorosilan (PTS, $\mathrm{C}_{6} \mathrm{H}_{5} \mathrm{SiCl}_{3}$ ) molekülü, NBO 3.1 ile Doğal Bağ Orbital (NBO) teorisi ile Gaussian09 programında çalışıldı. PTS için sadece $\pi-\pi^{*}$ geçişlerinin olduğu belirlenmiştir. Bu geçişlere ait donör-akseptör etkileşimleri ve stabilizasyon enerjileri hesaplandı. En yüksek geçiş enerjisi $\pi(\mathrm{C} 1-\mathrm{C} 6) \rightarrow \pi^{*}(\mathrm{C} 2-\mathrm{C} 3)$ geçişinin orbital etkileşiminde meydana geldi ve delokolize durumda olan bu orbital enerjisi yaklaşık $99.32 \mathrm{~kJ} \mathrm{~mol}^{-1}$ olarak hesaplandı. Yapılan NBO hesaplamalarının sonuçlarından, hibritleşmenin, elektronların p-orbitallerine yerleşerek meydana geldiği belirlendi. PTS için doğal yükler hesaplandı ve en güçlü polarizasyonun Si ve C3 atomları arasında olduğu tespit edildi. PTS halkası için Harmonik Osilatör Aromatiklik Ölçümü (HOMA) indeksi hesaplandı.

Anahtar Kelimeler: Feniltriklorosilan, NBO, Stabilizasyon enerjisi, Orbital etkileşimi, Polarizasyon. 


\section{Introduction}

Silane $\left(\mathrm{SiH}_{4}\right)$ is an inorganic compound with group 14 hydride compound, which has an important application as a precursor of elemental silicon, especially in semiconductor production and industry (Filtvedt et al., 2012; Liu et al., 2015; Zhang et al., 2018). Generally, silanes are used in sealants and adhesives, coatings, filler treatment, and surface treatment (Witucki, 1993; Child and Ooji, 1999). Trichlorosilane, a chlorinated complex of silane (TS; $\mathrm{HSiCl}_{3}$ ) is the most important precursor for the synthesis of many organosilicon derivatives. It takes a considerable part in the process of manufacturing extreme pure silicon in the semiconductor industry (Vorotyntsev et al., 2001; Fishman, 2008; Fester et al., 2010). TS is also a reagent in the conversion of benzoic acids to toluene derivatives; and used in surface science and nanotechnology to form self-assembled monolayers (SAMs) (Cech and Taboryski, 2012). Phenyltrichlorosilane (PTS; $\mathrm{C}_{6} \mathrm{H}_{5} \mathrm{SiCl}_{3}$ ), analyzed in present study, used to make silicones for water repellents, heat resistant paints, insulating resins. Also it uses in industries for production of metals, in cosmetics, chemical manufacturing, etc. Lei et al. (2015) reported that four silylating agents (one is PTS) were used as a silane modification of silicon dioxide $\left(\mathrm{SiO}_{2}\right)$ gate dielectric. This report was about that these silylating agents effect how on performance of field-effect transistor (FET).

In this study, Orbital interactions and strong stabilization energies of the optimized PTS molecule were calculated and analyzed with the NBO method. Orbital states of hybridizations were examined. The polarized states of the molecule were determined from their calculated natural charges.

\section{Theoretical Calculations}

In the calculations, it was used Lee-Yang-Parr correlation (Lee et al., 1988) that invention of Becke's three-parameter hybrid function (Becke, 1988). Molecule energies were minimized by DFT/B3LYP/6-311++G(d,p) level of approximation in gas phase. Stabilization energies and orbital interactions of the PTS were explained using the NBO method. The method was used considering Weinhold and Landis (2005), by NBO 3.1 (Reed et al., 1988). The approximate geometry of the PTS in three dimensions was drawn in the GaussView 5.0 molecular imaging program (Dennington et al., 2009) to get stable state and the space arrangement of the atoms in the molecule. All theoretical calculations were indicated in Gaussian 09 program (Frisch et al., 2009). 


\section{Findings and Discussion}

Figure 1 shows the optimized PTS using DFT with B3LYP/6-311++G(d,p) basis set and the molecule in minimum energy plotted with adopted atom numbers.

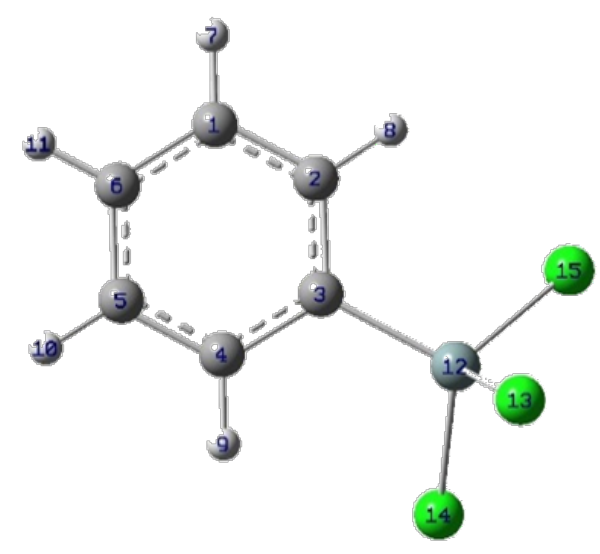

Figure 1. Optimized PTS scheme of PTS at B3LYP/6-311++G(d,p) basis set.

The electronic energy $(E)$, electronic+zero point vibrational energy $(E+Z P V)$ and Gibbs energy $(G)$ for PTS were calculated with B3LYP/6-311++G(d,p) basis set. After minimized, it was found approximately -1902.062, -1901.966 and -1902.003 Hartree, respectively.

Interaction energies between orbitals, $E(2)$, donor-acceptor NBOs are obtained from the second-order perturbation theory (Weinhold and Landis, 2005).

$$
E(2)=\Delta E_{i j}=q_{i} \frac{F_{i j}^{2}}{\varepsilon_{j}-\varepsilon_{i}}
$$

where $F_{i j}^{2}$ is the Fock matrix element between the $i$ and $j$ NBO orbitals, $q_{i}$ is the occupancy of the donor orbital, $\varepsilon_{j}$ and $\varepsilon_{i}$ are the energies of the acceptor and donor NBOs. It was found that all these transitions are $\pi-\pi^{*}$ transitions related to delocalization over the $C$ atoms. Total stabilization energy of donor and acceptor pairs was calculated as $506.57 \mathrm{~kJ} \mathrm{~mol}^{-1}$. As seen in Table 1, the most significant NBO interaction is $\pi(\mathrm{C} 1-\mathrm{C} 6) \rightarrow \pi^{*}(\mathrm{C} 2-\mathrm{C} 3)$, and orbital interaction energy was calculated about 99.32 $\mathrm{kJ} \mathrm{mol}^{-1}$. Stabilization energy values bigger than $10 \%$ were selected.

Table 1 shows the most relevant NBO interactions for PTS. These interactions are plotted also in Figure 2. It can be noticed that electrons are delocalized along the phenyl ring. The $\pi$-system of the molecule involves the orbital interaction types of A, B, C, D, E and F in Figure 2. The highest stabilization energy is the $\pi(\mathrm{C} 1-\mathrm{C} 6)-\pi^{*}(\mathrm{C} 2-\mathrm{C} 3)$ orbital interaction with $99.32 \mathrm{~kJ} \mathrm{~mol}^{-1}$. And the lowest one is $\pi(\mathrm{C} 2-\mathrm{C} 3)-\pi^{*}(\mathrm{C} 1-\mathrm{C} 6)$ orbital interaction with $73.48 \mathrm{~kJ} \mathrm{~mol}^{-1}$. 
Table 1. Donor and acceptor pairs and orbital energies for NBO pairs for ring as calculated by the Fock matrix equation (Eq.1) in the NBO basis for PTS ${ }^{\text {a }}$.

\begin{tabular}{cccccc}
\hline Pair & $\begin{array}{c}\text { Donor NBO } \\
(\boldsymbol{i})\end{array}$ & $\begin{array}{c}\text { Acceptor NBO } \\
(\boldsymbol{j})\end{array}$ & $\begin{array}{c}\boldsymbol{E}(\mathbf{2}) \\
\mathbf{k J ~ m o l} \mathbf{~}^{\mathbf{1}}\end{array}$ & $\begin{array}{c}\boldsymbol{\varepsilon}_{\mathbf{j}}-\boldsymbol{\varepsilon}_{\mathbf{i}} \\
\mathbf{a u}\end{array}$ & $\begin{array}{c}\boldsymbol{F}_{\boldsymbol{i j}} \\
\mathbf{a u}\end{array}$ \\
\hline $\mathrm{A}$ & $\pi(\mathrm{C} 1-\mathrm{C} 6)$ & $\pi^{*}(\mathrm{C} 2-\mathrm{C} 3)$ & 99.32 & 0.27 & 0.072 \\
$\mathrm{~B}$ & $\pi(\mathrm{C} 1-\mathrm{C} 6)$ & $\pi^{*}(\mathrm{C} 4-\mathrm{C} 5)$ & 79.50 & 0.28 & 0.066 \\
$\mathrm{C}$ & $\pi(\mathrm{C} 2-\mathrm{C} 3)$ & $\pi^{*}(\mathrm{C} 1-\mathrm{C} 6)$ & 73.48 & 0.29 & 0.064 \\
$\mathrm{D}$ & $\pi(\mathrm{C} 2-\mathrm{C} 3)$ & $\pi^{*}(\mathrm{C} 4-\mathrm{C} 5)$ & 86.65 & 0.29 & 0.069 \\
$\mathrm{E}$ & $\pi(\mathrm{C} 4-\mathrm{C} 5)$ & $\pi^{*}(\mathrm{C} 1-\mathrm{C} 6)$ & 88.24 & 0.28 & 0.070 \\
$\mathrm{~F}$ & $\pi(\mathrm{C} 4-\mathrm{C} 5)$ & $\pi^{*}(\mathrm{C} 2-\mathrm{C} 3)$ & 79.38 & 0.27 & 0.065 \\
\hline
\end{tabular}

a See atom numbering in Fig. 1.

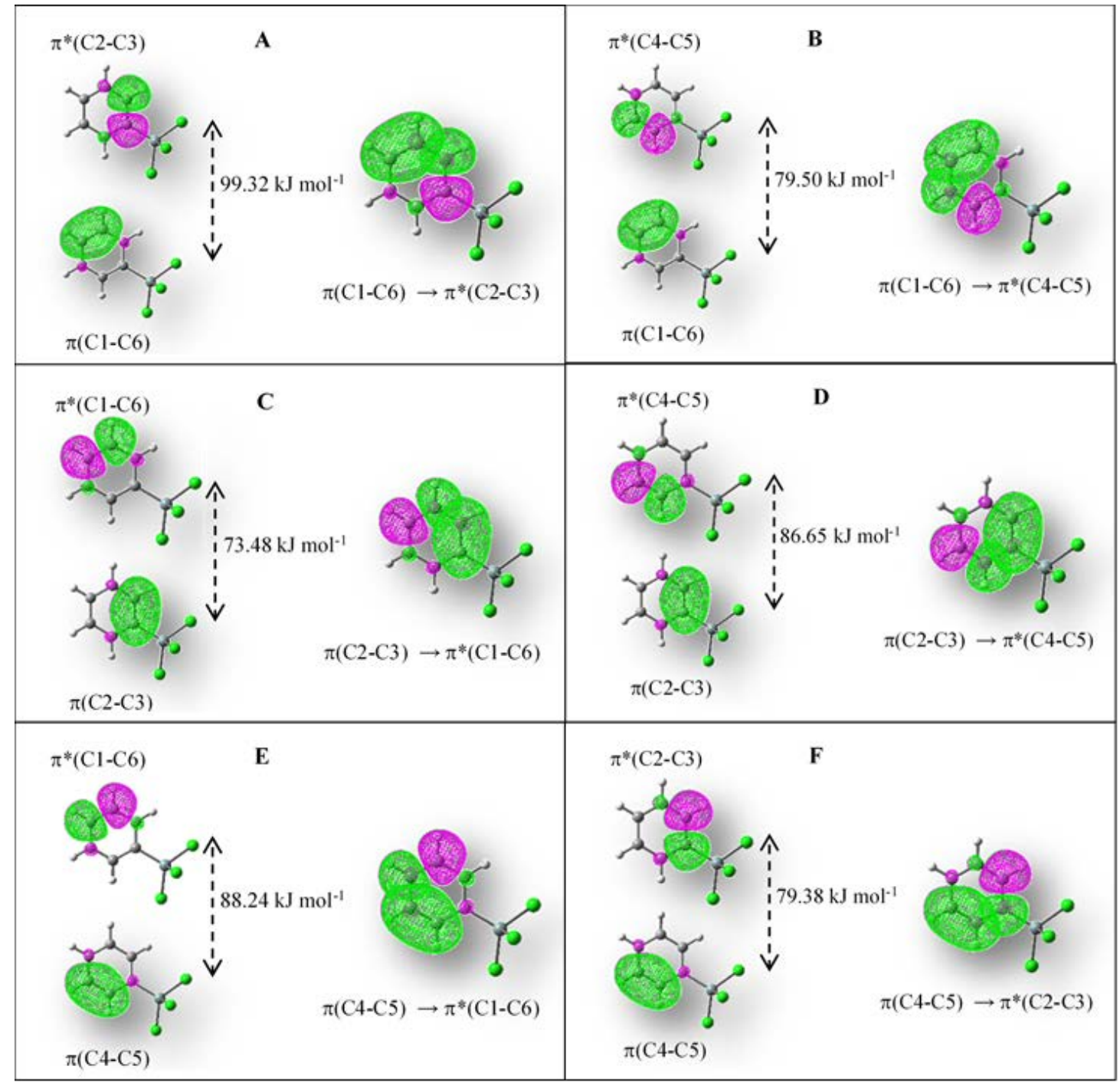

Figure 2. Electron density surfaces of donor-acceptor orbitals for PTS ring calculated at the DFT/B3LYP/6$311++G(d, p)$ method plotted the dominant orbital interactions (see Table 2). The electron density isovalues are equal to $0.02 \mathrm{e}$. Purple and green colors indicate to negative and positive wave function signs. 
Table 2. Orbitals, occupancy, coefficients and hybridization with stabilization energy values higher than $10 \%$ for PTS ring calculated using B3L YP/6-311++G(d,p) level.

\begin{tabular}{|c|c|c|c|c|c|}
\hline \multirow{2}{*}{ Group } & \multirow{2}{*}{ NBO } & \multirow{2}{*}{ Occupancy ratio } & \multicolumn{2}{|c|}{ Coefficients (\%) } & \multirow{2}{*}{ Hybridization ${ }^{\text {b }}$} \\
\hline & & & $A$ & B & \\
\hline \multirow{3}{*}{ donor } & $\pi(\mathrm{C} 1-\mathrm{C} 6)$ & 1.64161 & 50.90 & 49.10 & $0.7134 p+0.7007 p$ \\
\hline & $\pi(\mathrm{C} 2-\mathrm{C} 3)$ & 1.67307 & 45.35 & 54.65 & $0.6734 p+0.7393 p$ \\
\hline & $\pi(\mathrm{C} 4-\mathrm{C} 5)$ & 1.64883 & 48.95 & 51.05 & $0.6996 p+0.7145 p$ \\
\hline \multirow{3}{*}{ acceptor } & $\pi^{*}(\mathrm{C} 1-\mathrm{C} 6)$ & 0.31693 & 49.10 & 50.90 & $0.7007 p-0.7134 p$ \\
\hline & $\pi^{*}(\mathrm{C} 2-\mathrm{C} 3)$ & 0.37310 & 54.65 & 45.35 & $0.7393 p-0.6734 p$ \\
\hline & $\pi^{*}(\mathrm{C} 4-\mathrm{C} 5)$ & 0.30510 & 51.05 & 48.95 & $0.7145 p-0.6996 p$ \\
\hline
\end{tabular}

a The A and B values create a bond for the NBO orbitals of the atomic orbitals of the two atoms, corresponding to the contributions of the atoms that make up these pairs, and are obtained from the coefficients of the polarizations. ${ }^{\mathrm{b}}$ Definition of hybrid orbitals.

According to the NBO interactions, $\mathrm{C}$ atoms on ring were hybridized as $\mathrm{p}$ orbital and the strongest p hybridization was obtained in C1-C6 orbital interaction, and the percentage of coefficients were 50.90 for C1 and 49.10 for C6 for donor. Hybridization was the same for acceptor. Only the percentage of coefficients has changed from C1 to 49.10 and C6 to 50.90 .

Taking into account the stabilization energies of PTS ring higher than $10 \%$, the occupancy ratio of the bond orbitals, NBO coefficients of the atoms and their hybridizations are given in Table 2. This Table also presents the bonding percentage of atomic orbitals in each atom, subtracted from the NBO polarization coefficients for NBO orbitals. In the NBO analysis of PTS, the highest polarization values were observed in the case of the bond formed by the acceptor C2 atom with C3 atom. The C2O3 bond in the acceptor state is $\pi \rightarrow \pi^{*}$ contribution, and constitutes approximately $55 \%$ of the NBO stabilization energies.

Table 3. Donor and acceptor pairs and orbital energies for NBO pairs for $(\mathrm{C}-\mathrm{Si})-\left(\mathrm{Si}-\mathrm{Cl}_{13,14,15}\right)$ and $\mathrm{LP}(2) \mathrm{Cl}_{13,14,15}-(\mathrm{C}-\mathrm{Si})$ as calculated by the Fock matrix equation (Eq.1) in the NBO basis for PTS ${ }^{\text {a }}$.

\begin{tabular}{|c|c|c|c|c|c|}
\hline Pair & $\begin{array}{l}\text { Donor NBO } \\
\text { (i) }\end{array}$ & $\begin{array}{c}\text { Acceptor NBO } \\
(j)\end{array}$ & $\begin{array}{c}E(2) \\
\mathrm{kJ} \mathrm{mol}^{-1}\end{array}$ & $\begin{array}{c}\varepsilon_{j-} \varepsilon_{i} \\
\text { au }\end{array}$ & $\begin{array}{l}F_{i j} \\
\text { au }\end{array}$ \\
\hline G & $\sigma(\mathrm{C}-\mathrm{Si})$ & $\sigma^{*}\left(\mathrm{Si}-\mathrm{Cl}_{13}\right)$ & 9.82 & 0.66 & 0.036 \\
\hline $\mathrm{H}$ & $\sigma(\mathrm{C}-\mathrm{Si})$ & $\sigma^{*}\left(\mathrm{Si}-\mathrm{Cl}_{14}\right)$ & 10.12 & 0.66 & 0.036 \\
\hline I & $\sigma(\mathrm{C}-\mathrm{Si})$ & $\sigma^{*}\left(\mathrm{Si}-\mathrm{Cl}_{15}\right)$ & 10.16 & 0.66 & 0.036 \\
\hline $\mathrm{J}$ & $\mathrm{LP}(2) \mathrm{Cl}_{13}$ & $\sigma^{*}(\mathrm{C}-\mathrm{Si})$ & 28.84 & 0.53 & 0.055 \\
\hline K & $\mathrm{LP}(2) \mathrm{Cl}_{14}$ & $\sigma^{*}(\mathrm{C}-\mathrm{Si})$ & 25.12 & 0.54 & 0.051 \\
\hline $\mathrm{L}$ & $\mathrm{LP}(2) \mathrm{Cl}_{15}$ & $\sigma^{*}(\mathrm{C}-\mathrm{Si})$ & 25.08 & 0.54 & 0.051 \\
\hline M & $\mathrm{LP}(3) \mathrm{Cl}_{14}$ & $\sigma^{*}(\mathrm{C}-\mathrm{Si})$ & 3.55 & 0.54 & 0.019 \\
\hline $\mathrm{N}$ & $\mathrm{LP}(3) \mathrm{Cl}_{15}$ & $\sigma^{*}(\mathrm{C}-\mathrm{Si})$ & 3.59 & 0.54 & 0.019 \\
\hline
\end{tabular}

\footnotetext{
a See atom numbering in Fig. 1.
} 
Considering the ring-related C-(Si-Cl) and $\mathrm{LP}(2) \mathrm{Cl}(13,14,15)-(\mathrm{C}-\mathrm{Si})$ effects, it was calculated that the highest stabilization energy was in the case of $\mathrm{LP}(2) \mathrm{Cl} 13-(\mathrm{C}-\mathrm{Si})$ orbital interaction at a value of $28.84 \mathrm{~kJ} \mathrm{~mol}^{-1}$. C-Si and $\mathrm{Si}-\mathrm{Cl}(13,14,15)$ stabilization energies showing $\sigma-\sigma *$ interaction are given in the Table 3 and it was found that the most effective state was in the case of $\sigma(\mathrm{C}-\mathrm{Si})-\sigma *(\mathrm{Si}-$ Cl15) with a slight difference. It can be seen from the table 3 that the stabilization energies resulting from $\mathrm{LP}(3) \mathrm{Cl}(14,15)$ - (C-Si) orbital interactions are very small and ca $3.6 \mathrm{~kJ} \mathrm{~mol}^{-1}$.

Table 4. Orbitals, occupancy, coefficients and hybridization between C-Si and Si-Cl(13,14,15) and Cl $(13,14,15)$-C-Si for PTS calculated using B3LYP/6-311++G(d,p) level.

\begin{tabular}{|c|c|c|c|c|c|}
\hline \multirow{2}{*}{ Group } & \multirow{2}{*}{ NBO } & \multirow{2}{*}{ Occupancy ratio } & \multicolumn{2}{|c|}{ Coefficients (\%) } & \multirow{2}{*}{ Hybridization $^{b}$} \\
\hline & & & $A$ & $B$ & \\
\hline \multirow{6}{*}{ donor } & $\sigma(\mathrm{C}-\mathrm{Si})$ & 1.95370 & 70.49 & 29.51 & $0.8396 \mathrm{sp}^{2.47}+0.5432 \mathrm{sp}^{2.01}$ \\
\hline & $\mathrm{LP}(2) \mathrm{Cl}_{13}$ & 1.93524 & & & $\mathrm{spd}^{0.38}$ \\
\hline & $\mathrm{LP}(2) \mathrm{Cl}_{14}$ & 1.93716 & & & $\mathrm{spd}^{0.22}$ \\
\hline & $\mathrm{LP}(2) \mathrm{Cl}_{15}$ & 1.93712 & & & $\mathrm{spd}^{0.22}$ \\
\hline & $\mathrm{LP}(3) \mathrm{Cl}_{14}$ & 1.93164 & & & $\operatorname{spd}^{1.33}$ \\
\hline & $\mathrm{LP}(3) \mathrm{Cl}_{15}$ & 1.93173 & & & $\operatorname{spd}^{1.50}$ \\
\hline \multirow{4}{*}{ acceptor } & $\sigma^{*}\left(\mathrm{Si}-\mathrm{Cl}_{13}\right)$ & 0.11982 & 72.48 & 27.52 & $0.8514 \mathrm{sp}^{3.36}-0.5246 \mathrm{sp}^{3.98}$ \\
\hline & $\sigma^{*}\left(\mathrm{Si}-\mathrm{Cl}_{14}\right)$ & 0.10885 & 72.53 & 27.47 & $0.8516 \mathrm{sp}^{3.38}-0.5241 \mathrm{sp}^{3.90}$ \\
\hline & $\sigma^{*}\left(\mathrm{Si}-\mathrm{Cl}_{15}\right)$ & 0.10854 & 72.53 & 27.47 & $0.8516 \mathrm{sp}^{3.38}-0.5241 \mathrm{sp}^{3.90}$ \\
\hline & $\sigma^{*}(\mathrm{C}-\mathrm{Si})$ & 0.11582 & 29.51 & 70.49 & $0.5432 \mathrm{sp}^{2.47}-0.8396 \mathrm{sp}^{2.01}$ \\
\hline
\end{tabular}

\footnotetext{
a The A and B values create a bond for the NBO orbitals of the atomic orbitals of the two atoms, corresponding to the contributions of the atoms that formed these pairs, and are obtained from the coefficients of the polarizations.

${ }^{\mathrm{b}}$ Definition of hybrid orbitals.
} 


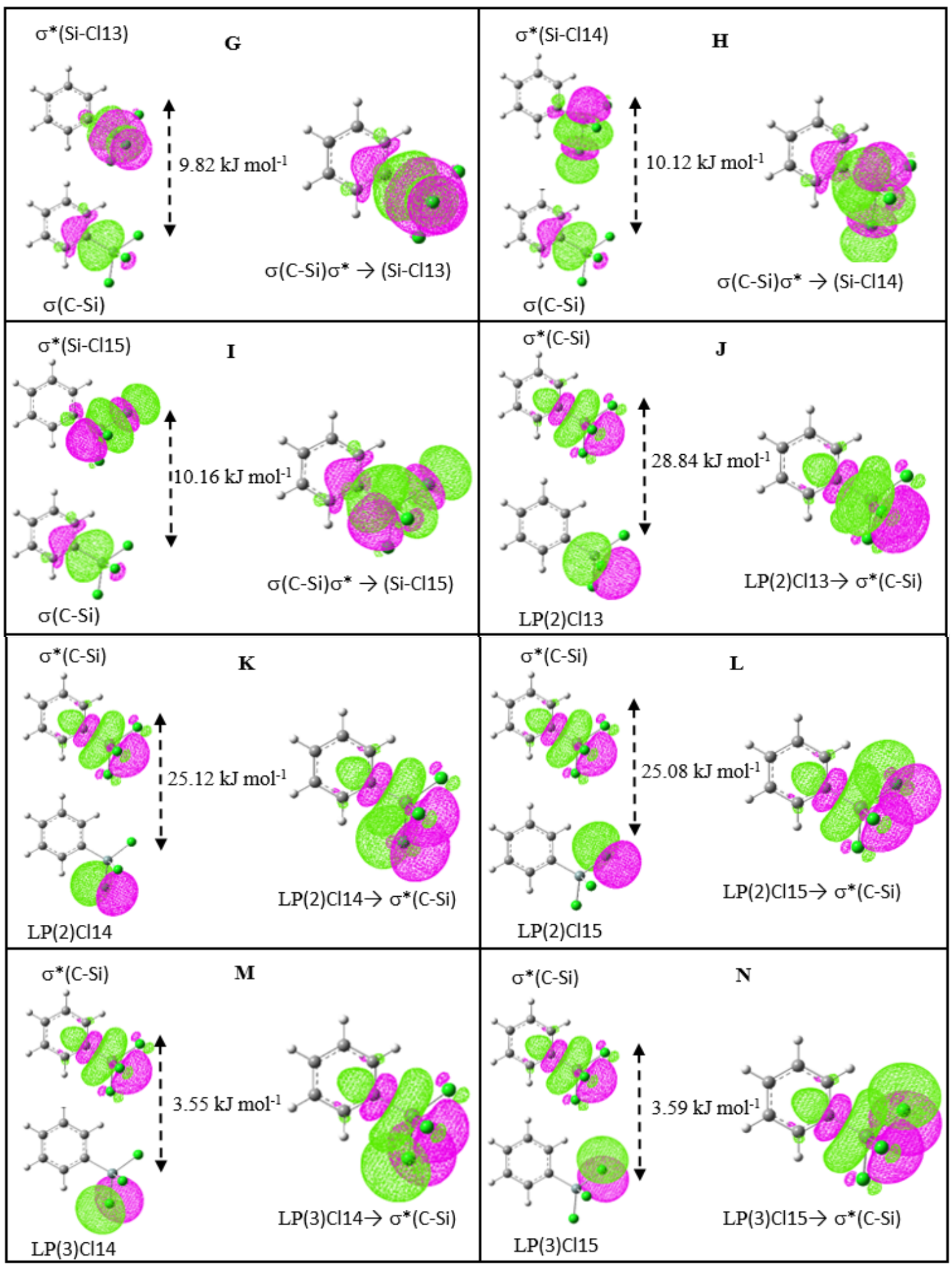

Figure 3. Electron density surfaces of donor-acceptor orbitals for (C-Si)-(Si-Cl $\left.\mathrm{Cl}_{13,14,15}\right)$ and $\mathrm{LP}(2)$ Cl(13,14,15)-(C-Si) calculated at the DFT/B3LYP/6-311++G(d,p) method plotted the dominant orbital interactions (see Table XX). The electron density isovalues are equal to 0.02 e. Purple and green colors indicate to negative and positive wave function signs.

The calculated natural hybrids on atoms were given in Table 4. From Table 4 it was noted that the maximum occupancy 1.95370 was obtained for $\sigma(\mathrm{C}-\mathrm{Si})$. The strongest electron donation occurs from a $\mathrm{LP}(2) \mathrm{Cl} 13$ to the antibonding acceptor $\sigma^{*}(\mathrm{C}-\mathrm{Si})$ orbital. 
Table 5. Transition state, type, relative energy $(\Delta \mathrm{E})$, wavelength of the absorption $(\lambda)$ and oscillator strength (f) calculated by TD-DFT(B3LYP/6-311++G(d,p)) method for PTS.

\begin{tabular}{|c|c|c|c|c|c|}
\hline State & & Type & $\Delta E(\mathrm{eV})$ & $\lambda(\mathbf{n m})$ & $f$ \\
\hline $\mathrm{S}_{1}$ & $\pi \pi^{*}$ & $\mathrm{HOMO} \rightarrow \mathrm{LUMO}$ & 5.15 & 240.83 & 0.0097 \\
\hline $\mathrm{S}_{2}$ & $\pi \pi^{*}$ & HOMO-1 $\rightarrow$ LUMO & 5.70 & 217.45 & 0.1356 \\
\hline $\mathrm{S}_{3}$ & $\pi \pi^{*}$ & $\mathrm{HOMO} \rightarrow \mathrm{LUMO}_{+2}$ & 6.20 & 200.06 & 0.0000 \\
\hline $\mathrm{S}_{4}$ & $\pi \pi^{*}$ & $\mathrm{HOMO}_{-1} \rightarrow \mathrm{LUMO}_{+2}$ & 6.22 & 199.34 & 0.0002 \\
\hline $\mathrm{S}_{5}$ & $\pi \pi^{*}$ & $\mathrm{HOMO}_{-3} \rightarrow$ LUMO & 6.24 & 198.82 & 0.0109 \\
\hline $\mathrm{S}_{6}$ & $\pi \pi^{*}$ & $\mathrm{HOMO}_{-2} \rightarrow$ LUMO & 6.42 & 193.06 & 0.0021 \\
\hline $\mathrm{T}_{1}$ & $\pi \pi^{*}$ & $\mathrm{HOMO}_{-1} \rightarrow$ LUMO & 3.69 & 336.22 & 0.0000 \\
\hline $\mathrm{T}_{2}$ & $\pi \pi^{*}$ & $\mathrm{HOMO} \rightarrow \mathrm{LUMO}$ & 4.36 & 284.53 & 0.0000 \\
\hline $\mathrm{T}_{3}$ & $\pi \pi^{*}$ & $\mathrm{HOMO} \rightarrow \mathrm{LUMO}_{+1}$ & 4.57 & 271.37 & 0.0000 \\
\hline $\mathrm{T}_{4}$ & $\pi \pi^{*}$ & $\mathrm{HOMO}_{-1} \rightarrow \mathrm{LUMO}_{+1}$ & 5.07 & 244.63 & 0.0000 \\
\hline $\mathrm{T}_{5}$ & $\pi \pi^{*}$ & $\mathrm{HOMO}_{-3} \rightarrow$ LUMO & 6.09 & 203.63 & 0.0000 \\
\hline $\mathrm{T}_{6}$ & $\pi \pi^{*}$ & $\mathrm{HOMO}_{-1} \rightarrow \mathrm{LUMO}_{+2}$ & 6.15 & 201.73 & 0.0000 \\
\hline
\end{tabular}

The electronic transition properties which include the excitation wavelength and relative intensities (oscillator strengths) were obtained using time dependent density functional theory (TDDFT) calculation. According to the calculation, all singlet and triplet transitions were found as $\pi-\pi^{*}$ transitions. The strongest oscillator strength was observed in the $\mathrm{S}_{2}$ state (HOMO$-1 \rightarrow$ LUMO) and the energy $5.70 \mathrm{eV}$ (Table 5). As seen from the NBO results mentioned above, stabilization via the $\pi$ system was clearly dominant.

Delocalization in cyclic structures were defined by Kruszewski and Krygowski and named Harmonic Oscillator Measure of Aromaticity (HOMA) index (Kruszewski and Krygowski, 1972; Krygowski, 1993; Krygowski and Cyranski. 1996). The HOMA index equation is given as:

$$
H O M A=1-\frac{\alpha}{n} \sum_{i=1}^{n}\left(R_{o p t}-R_{i}\right)^{2}
$$

In this equation, $n$ is the number of bonds, $\alpha$ is an empirical constant value. For a non-aromatic system, HOMA is equal to " 0 ”. In case of HOMA is equal to " 1 ” for perfectly aromatic systems, the optimal value $R_{\text {opt }}$ value is a constant value. $R_{i}$ refers to the length of the bond that is constantly wrapped in 
the ring. This equation is a simple equation, one of the best equations showing the measure of aromaticity, and also a good measure of $\pi$-electron delocalization (Glendening et al., 1993).

$\pi$-delocalization was observed in PTS and HOMA index was calculated using the equation above, and found ca.0.974. $\alpha$ and $R_{\text {opt }}$ constants are taken as $257.7 \AA^{-2}$ and $1.388 \AA$ for C-C bonds, respectively (Carey and Sundberg, 2007). $R_{i}$ for C-C bonds of PTS ring are given in Table 6. In this case, it can be said that the degree of aromaticity calculated for the PTS molecule is high enough. In literature, HOMA index were found 0.991, 0.811, 0.718 and 0.741 for benzene, naphthalene, anthracene and phenanthrene, respectively (Krygowski and Cyranski, 1996). Kus et al. (2007) were found the HOMA index as a 0.987 for the benzene ring of coumarin.

Table 6. Bond lengths of PTS ${ }^{\text {a }}$, calculated using B3LYP/6-311++G(d,p) level.

\begin{tabular}{ccc}
\hline Name & Definition & Value $(\AA)$ \\
\hline R1 & $\mathrm{R}(1,2)$ & 1.3924 \\
R2 & $\mathrm{R}(1,6)$ & 1.3937 \\
R3 & $\mathrm{R}(1,7)$ & 1.0840 \\
R4 & $\mathrm{R}(2,3)$ & 1.4038 \\
R5 & $\mathrm{R}(2,8)$ & 1.0842 \\
R6 & $\mathrm{R}(3,4)$ & 1.4039 \\
R7 & $\mathrm{R}(3,12)$ & 1.8566 \\
R8 & $\mathrm{R}(4,5)$ & 1.3923 \\
R9 & $\mathrm{R}(4,9)$ & 1.0842 \\
R10 & $\mathrm{R}(5,6)$ & 1.3938 \\
R11 & $\mathrm{R}(5,10)$ & 1.0840 \\
R12 & $\mathrm{R}(6,11)$ & 1.0842 \\
R13 & $\mathrm{R}(12,13)$ & 2.0648 \\
R14 & $\mathrm{R}(12,14)$ & 2.0633 \\
R15 & $\mathrm{R}(12,15)$ & 2.0633 \\
\hline
\end{tabular}

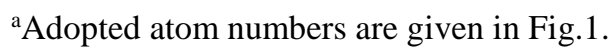

The electrons of covalently bonded molecules are assumed to exist in molecular orbitals formed by orbitals of atoms. Each of these orbitals has different steady state energies. Filled orbitals are donors and empty orbitals are acceptors. The energy difference between the Highest Occupied Molecular Orbital (HOMO) and Lowest Unoccupied Molecular Orbital (LUMO) for PTS is 6.04 $\mathrm{eV}$ and plotted in Fig. 4. The HOMO orbital of the PTS was mostly concentrated on the phenyl ring, while LUMO orbital was concentrated even phenyl ring or chlorosilane group. 


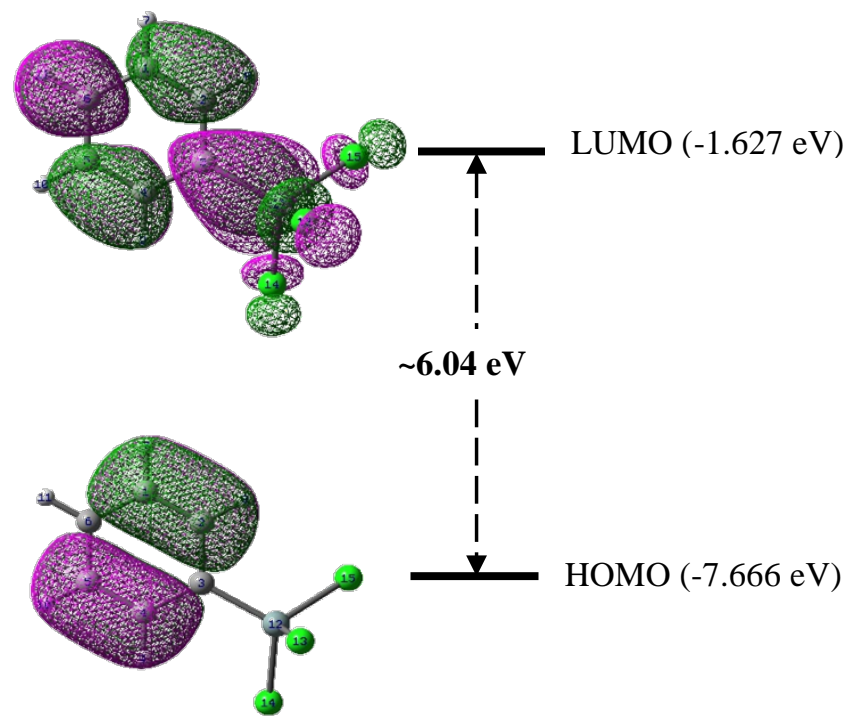

Figure 4. Orbital density of HOMO-LUMO and energy gap for PTS.

The natural charges for PTS are shown in Table 7. The charges on atoms are identical. The dipole interactions can be related with the strongly polarized Si-C bond in the molecule (charges on Si and C3 are of $c a .+1.37$ e and $c a$. -0.55 e, respectively).

Table 7. NBO charges ${ }^{\mathrm{a}}$ for PTS calculated using B3LYP/6-311++G(d,p) level ${ }^{\mathrm{b}}$.

\begin{tabular}{cc}
\hline Atom & NBO charge \\
\hline C1 & -0.20027 \\
C2 & -0.16992 \\
C3 & -0.55066 \\
C4 & -0.16982 \\
C5 & -0.20024 \\
C6 & -0.17751 \\
H7 & 0.21246 \\
H8 & 0.21694 \\
H9 & 0.21673 \\
H10 & 0.21247 \\
H11 & 0.21074 \\
Si12 & 1.36691 \\
Cl13 & -0.32100 \\
Cl14 & -0.32341 \\
Cl15 & -0.32344 \\
\hline
\end{tabular}

a Electron unit; e $=1.60217646 \times 10^{-19} \mathrm{C}$.

${ }^{\mathrm{b}}$ Fig. 1 shows atom numbers.

Surface map of Molecular Electrostatic Potential (MEP) of PTS was drawn using GaussView5, and given in Fig. 5. The map visualizes charge regions of the molecule. In scale bar, the red and blue colours indicate negative and positive values, respectively. These values are between -1.544e-2 (max. red region) and $+1544 \mathrm{e}-2$ (max. blue region). The map of PTS showed that the negative electrostatic potentials (red region, electrophilic attack) were intensified around the $\mathrm{Cl}$ atoms while the maximum 
electrostatic potential (blue region, nucleophilic attack) were intensified around the $\mathrm{H}$ atoms. From Fig. 5, it can be seen that between $\mathrm{Si}$ and $\mathrm{Cl}$ atoms attraction is more concantrated.

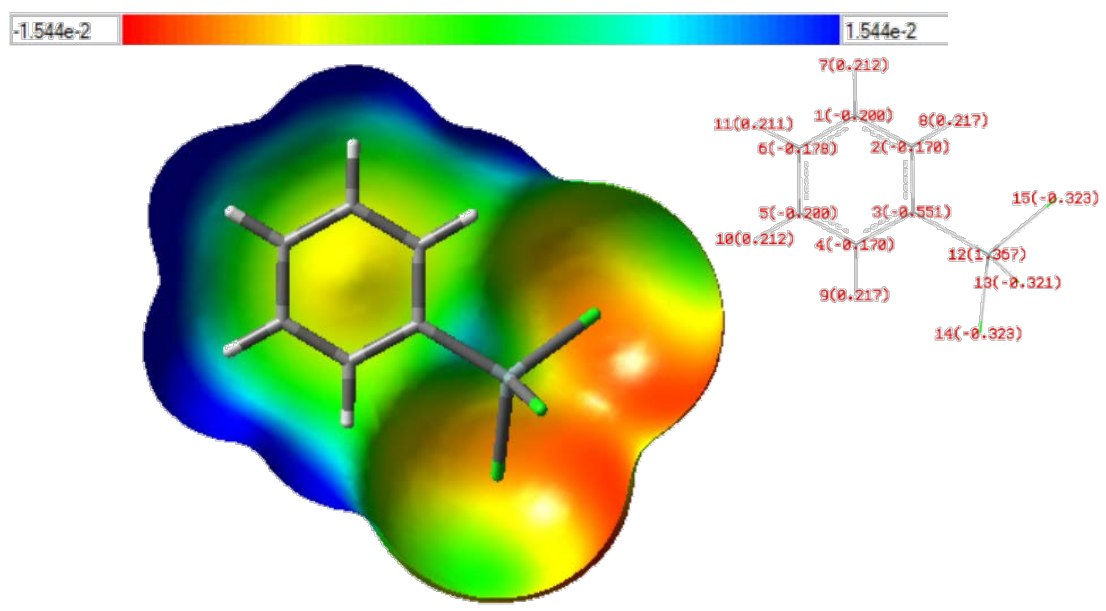

Figure 5. MEP surface for PTS (inset natural charges), calculated using B3LYP/6-311++G(d,p) level.

\section{Conclusions}

PTS molecule in minimum energy state were calculated theoretically in gas phase using DFTB3LYP/6-311++G(d,p) method. The donor-acceptor orbital interactions of PTS were analyzed using the NBO method. The hybridization was found to be in p-orbitals. $\pi-\pi *$ transitions were observed in the ring due to delocalization. Depending on the orbital interactions, stabilization energies of PTS were calculated considering for the highest values. These interactions were observed between $\mathrm{C}$ atoms. Total stabilization energy for C-C orbital interactions was found $c a$. $506.57 \mathrm{~kJ} \mathrm{~mol}^{-1}$. TD-DFT calculations were carried out to explore the electronically excited states of PTS and found $\pi$ system was clearly dominant. . HOMA index for PTS ring was 0.974. HOMO-LUMO energy difference was calculated as ca. $6.04 \mathrm{eV}$, and orbital distributions were drawn. It was found that Si-C3 bond has the highest polarized using NBO charge analysis. MEP surface of PTS was plotted and analyzed.

\section{References}

Becke, A.D., (1988). Density-functional exchange-energy approximation with correct asymptotic behavior. Phys. Rev. A, 38, 3098-3100.

Francis A. Carey, Richard J. Sundberg. (2007). Advanced Organic Chemistry: Part A: Structure and Mechanisms. $5^{\text {th }}$ Ed., Springer: USA.

Cech, J., Taboryski, R. (2012). Stability of FDTS monolayer coating on aluminum injection molding tools, Applied Surface Science, 259, 538-541.

Child, T. F. and Ooij, W. J. van. (1999). Application of silane technology to prevent corrosion of metals and improve paint adhesion, Transactions of the Institute of Metal Finishing, 77(2), 64-70. 
Dennington, R., Keith, T., and Millam, J. (2009). GaussView, Version 5. Semichem Inc., Shawnee Mission, KS.

Fester, G. W., Eckstein, J., Gerlach, D., Wagler, J., Brendler, E., and Kroke, E. (2010). Reactions of hydridochlorosilanes with 2,2'-bipyridine and 1,10-phenanthroline: Complexation versus dismutation and metal-catalyst-free 1,4-hydrosilylation, Inorganic Chemistry, 49(6), 2667-2673.

Filtvedt, W. O., Holt, A., Ramachandran, P. A., and Melaaen, M. C. (2012). Chemical vapor deposition of silicon from silane: Review of growthmechanisms and modeling/scaleup of fluidized bed reactors, Solar Energy Materials \& Solar Cells, 107, 188-200.

Fishman, O. S. (2008). Solar silicon, Advanced Materials and Processes, 166(9), 39-40.

Frisch, M. J., Trucks, G. W., Schlegel, H. B., Scuseria, G. E., Robb, M. A., Cheeseman, J. R., Scalmani, G., Barone, V., Mennucci, B., Petersson, G. A., Nakatsuji, H., Caricato, M., Li, X., Hratchian, H. P., Izmaylov, A. F., Bloino, J., Zheng, G., Sonnenberg, J. L., Hada, M., Ehara, M., Toyota, K., Fukuda, R., Hasegawa, J., Ishida, M., Nakajima, T., Honda, Y., Kitao, O., Nakai, H., Vreven, T., Montgomery, J. A., Peralta Jr, J. E., Ogliaro, F., Bearpark, M., Heyd, J. J., Brothers, E., Kudin, K. N., Staroverov, V. N., Kobayashi, R., Normand, J., Raghavachari, K., Rendell, A., Burant, J. C., Iyengar, S. S., Tomasi, J., Cossi, M., Rega, N., Millam, J. M., Klene, M., Knox, J. E., Cross, J. B., Bakken, V., Adamo, C., Jaramillo, J., Gomperts, R., Stratmann, R. E., Yazyev, O., Austin, A. J., Cammi, R., Pomelli, C., Ochterski, J. W., Martin, R. L., Morokuma, K., Zakrzewski, V. G., Voth, G. A., Salvador, P., Dannenberg, J. J., Dapprich, S., Daniels, A. D., Farkas, O., Foresman, J. B., Ortiz, J. V., Cioslowski, J., and Fox, D. J., 2009, Gaussian 09, Revision A.0.2, Gaussian, Inc., Wallingford CT.

Glendening, E. D., Faust, R., Streitwieser, A., Vollhardt, K. P. C., and Weinhold, F. (1993). The Role of Delocalization in Benzene, Journal of the American Chemical Society,115, 10952-10957.

Kus, N., Breda, S., Reva, I., Tasal, E., Ogretir, C., and Fausto, R. (2007). FTIR Spectroscopic and Theoretical Study of the Photochemistry of Matrix-isolated Coumarin, Photochemistry and Photobiology, 83, 12371253.

Kruszewski, J. and T. M. Krygowski. (1972). Definition of aromaticity basing on harmonic oscillator model. Tetrahedron Letters, 13, 3839-3842.

Krygowski, T. M. (1993). Crystallographic studies of intermolecular and intramolecular interactions reflected in aromatic character of p-electron systems. The Journal for Chemical Information and Computer Sciences, 33, 70-78.

Krygowski, T. M. and M. Cyranski. (1996). Separation of the energetic and geometric contributions to the aromaticity of p-electron carbocyclics. Tetrahedron, 52, 1713-1722.

Lee, C., Yang, W., and Parr, R. G. (1988). Development of the Colle-Salvetti correlation-energy formula into a functional of the electron density, Physical Review B, 37, 785-789.

Lei, Y., Wu, B., Chan, W.-K. E., Zhu, F., and Ong, B. S. (2015). Engineering gate dielectric surface properties for enhanced polymer field-effect transistor performance, Journal of Materials Chemistry C, 3, 1226712272.

Liu, S.-S., Li, H., and Xiao, W.-D. (2015). Sintering effect on crystallite size, hydrogen bond structure andmorphology of the silane-derived silicon powders, Powder Technology, 273, 40-46.

Reed, A.E., Curtiss, L.A., and Weinhold, F., (1988). Intermolecular interactions from a natural bond orbital, donor-acceptor viewpoint. Chemical Reviews, 88, 899-926.

Vorotyntsev, V. M., Mochalov, G. M., and Nipruk, O. V. (2001). Synthesis of monosilane by catalytic disproportionation of trichlorosilane in a reaction-rectification apparatus with recycle, Russian Journal of Applied Chemistry, 74(4), 621-625.

Weinhold, F., and Landis, C. R. (2005). Valency and Bonding. A Natural Bond Orbital Donor-Acceptor Perspective. Cambridge University Press: New York.

Witucki, G. L. (1993). A silane primer: Chemistry and applications of aIkoxy silanes, Journal of Coatings Technology, 65(822), 57-60.

Zhang, P., Duan, J., Chen, G., Li, J., and Wang, W. (2018). Production of polycrystalline silicon from silane pyrolysis: A review of fines formation, Solar Energy, 175, 44-53. 